\title{
Indikator Input Sistem Surveillance Demam Berdarah Dengue (DBD) di Kota Yogyakarta
}

\author{
M. Syairaji ${ }^{1}$, Dian Budi Santoso ${ }^{2}$ \\ 1,2Sekolah Vokasi Universitas Gadjah Mada \\ email:1msyairaji@ugm.ac.id², dianbudisantoso@ugm.ac.id ${ }^{2}$
}

\begin{abstract}
To control the burden of the disease, surveillance system have a major role. The aim of study is to evaluate DHF surveillance system particularly in input indicators such as personnel, finance, standard and guidelines, forms, and also computers. A quantitative approach with descriptive cross sectional study design was conducted in August 2017. Population are all DHF surveillance officer in primarily health care around Yogyakarta City. Total sampling as sampling method and interviewed using structured questionnaire for data collection. Univariate data analysis involved to describe percentage distribution of research variables. Personnel indicators, average of age is 46 years old, $88.89 \%$ graduated from D3 environmental health. $44.44 \%$ have attended training for DHF Surveillance and $61 \%$ have doubled job. In budgeting aspect, $72.22 \%$ have funding for operational of DHF surveillance and most of it came from regional expenditure budget. More than $70 \%$ Primarily Health Care have Standard Operating Procedure (SOP) and computers. For availability of forms, 38\% did not have forms $K-D B D, W 2 D B D, K D / P K M$, and DP-DBD.There are some lacks on DHF Surveillance in Yogyakarta City. Major findings of this research are, in man aspect, age and doubled job and unavailability of some important forms for DHF Surveillance such as K-DBD, W2 DBD, KD/PKM, and DP-DBD. Recommendation for Primarily Health Care are to do rejuvenation of personnel and do new staff recruitment to complete all kind of health staff that should be in there.
\end{abstract}

Keyword: evaluation, surveillance, $D H F$

\begin{abstract}
ABSTRAK
Surveilans memiliki peranan yang sangat penting dalam hal deteksi pengendalian Demam Berdarah Dengue (DBD)dan analisis tren. Tujuan penelitian ini adalah untuk mengevaluasi sistem surveilans DBD khususnya pada indikator input yakni petugas, pembiayaan, ketersediaan SOP, formulir pelaporan, dan komputer.Penelitian ini merupakan penelitian kuantitatif dengan rancangan cross sectional deskriptif. Waktu penelitian selama bulan agustus 2017. Populasi adalah seluruh petugas surveilans Puskesmas wilayah Kota Yogyakarta. metode sampling adalah total sampling dimana pengambilan data dengan wawancara menggunakan kuesioner terstruktur. Analisis univariat dalam bentuk persentase.Indikator petugas, rata-rata berumur 48 tahun. $88.89 \%$ lulusan D3 kesehatan lingkungan, 44.44\% pernah mengikuti 2 kali atau lebih pelatihan mengenai program surveilans DBD. 61\% petugas surveilans DBD memiliki jabatan rangkap. Aspek pembiayaan, $72.22 \%$ menyatakan terdapat biaya untuk operasional surveilans DBD dengan sumber utama APBD. Lebih dari 70\% Puskesmas memiliki Standard Operating Procedure (SOP) surveilans DBD dan komputer pada aspek ketersediaan formulir, lebih dari 38\% Puskesmas tidak tersedia formulir K-DBD, W2 DBD, KD/PKM, dan DP-DBD. Temuan major yang didapatkan antara lain pada aspek umur dan jumlah jabatan rangkap (Man), serta ketersedian formulir khususnya formulir yang wajib diisi dan dilaporkan oleh Puskesmas seperti formulir K-DBD, W2 DBD, KD/PKM, dan DP-DBD. Saran yang dapat diberikan antara lain peremajaan petugas surveilans DBD Puskesmas dan melakukan rekrutmen petugas baru untuk melengkapi kurangnya jenis-jenis tenaga kesehatan di Puskesmas yang nantinya diharapkan petugas dengan jabatan rangkap akan berkurang.
\end{abstract}

Kata kunci: evaluasi, surveilans, DBD 


\section{PENDAHULUAN}

Sampai sekarang Demam Berdarah Dengue (DBD) masih menjadi prioritas internasional terkait masalah penyakit menular. Pada tahun 2012, DBD menduduki rangking pertama sebagai mosquito-borne viral desease yang paling penting di dunia. DBD dapat menyebabkan beban masalah yang besar (burden of desease) pada masyarakat, sistem kesehatan, dan ekonomi pada negara-negara endemik. Selama 5 dekade terakhir insidensi DBD meningkat 30 kali lipat. WHO memperkirakan 50-100 juta infeksi baru terjadi setiap tahunnya di lebih dari 100 negaranegara endemik dengan peningkatan ratusan ribu kasus yang parah termasuk 20.000 orang yang meninggal akibat DBD dan 264 disability-adjusted life years per satu juta penduduk pertahunnya hilang (WHO, 2012).

DBD di Indonesia masih merupakan masalah yang cukup besar. Pada tahun 2014 terdapat 100.347 kasus DBD dengan IR sebesar 39,80 per 100.000 penduduk. Angka ini meningkat pada tahun 2015 menjadi 129.650 dengan IR 50,75 per 100.000 penduduk (Kemenkes, 2016). Kota Yogyakarta menjadi salah satu daerah dengan IR DBD yang tinggi bahkan melebihi angka nasional yakni 101 per 100.000 penduduk pada tahun 2014, sedangkan untuk Case Fatality Rate (CFR) masih berada di bawah batas nasional (CFR < 1\%) yakni sebesar 0,73\% (DKK Yogyakarta, 2015).

Surveilans adalah kegiatan mengumpulkan, analisis, dan interpretasi data outcome spesifik secara terus menerus dan digunakan dalam hal perencanaan, implementasi, dan evaluasi kebijakan kesehatan. Surveilans penyakit menular memiliki dua fungsi utama yakni kewaspadaan dini terhadap masalah-masalah kesehatan seperti KLB dan untuk memonitoring fungsi program-program kesehatan(WHO, 2006). Penyelenggaraan surveilans kesehatan dilakukan melalui pengumpulan data, analisis data, dan diseminasi sebagai satu kesatuan yang tidak terpisahkan untuk menghasilkan informasi yang objektif, terukur, dapat dibandingkan antar waktu, antar wilayah, dan antar kelompok masyarakat sebagai bahan pengambilan keputusan . Surveilans memiliki peranan penting dalam penanggulangan penyakit menular khususnya DBD. Dengan adanya sistem surveilans DBD yang berkualitas maka diharapkan insidensi dapat ditekan dan KLB dapat di cegah dan dikendalikan penyebarannya (Permenkes, 2014).
Evaluasi sistem surveilans dapat mendukung penggunaan sumber daya dalam upaya kesehatan masyarakat secara optimal dengan memastikan hanya masalah kesehatan penting yang akan dipantau, selain itu evaluasi juga berguna agar pelaksanaan surveilans dapat berjalan dengan efisien (CDC, 1988)

Menurut WHO (2006), dibutuhkan indikatorindikator sebagai alat dalam monitoring dan evaluasi. Indikator tersebut adalah variabel yang dapat diukur berulang kali dan dapat menyediakan pengukuran untuk mendeteksi perubahan dalam sistem surveilans. Indikator-indikator ini menyediakan informasi terhadap status sistem serta bagian-bagian yang perlu ditingkatkan. Indikator biasanya disajikan bisa dalam bentuk perhitungan sederhana, proporsi, rates, atau rasio. Berdasarkan Logical Framework Approach (LFA), terdapat lima tipe indikator, yakni input, proses, output, outcome dan impact.Indikator input adalah sumber daya yang dibutuhkan dalam pengimplementasian sistem surveilans. Indikator ini terdiri atas petugas, budgeting/pembiayaan, standar dan guidelines, fasilitas komunikasi, formulir surveilans, computer, persediaan untuk respon darurat, dan logistik lain yang diperlukan (WHO, 2006).

Penelitian terkait evaluasi surveilans Demam Berdarah Dengue di Kota Yogyakarta yang terpublikasi masih sangat jarang ditemukan sehingga penelitian ini perlu dilakukan untuk dapat mengetahui situasi dan kondisi sistem surveilans di Kota Yogyakarta khususnya pada aspek input. Tujuan penelitian ini adalah untuk mengetahui gambaran sistem surveilans DBD di Kota Yogyakarta pada indikator input yakni petugas (Man), pembiayaan (Money), standar dan guideline (Method), formulir surveilans (Material), dan Komputer (Machine).

\section{METODE}

Penelitian ini menggunakan pendekatan kuantitatif dengan desain penelitian observational deskriptif. Lokasi penelitian adalah seluruh Puskesmas yang berada di wilayah kerja Dinas Kesehatan Kota Yogyakarta Provinsi Daerah Istimewa Yogyakarta (DIY) dengan waktu penelitian dari Bulan Juli Oktober 2017.

Populasi dalam penelitian ini adalah petugas surveilans DBD Puskesmas di seluruh wilayah Kota Yogyakarta yang terdiri dari 18 Puskesmas. Metode pengumpulan data menggunakan total sampling dengan eligibility criteria bersedia 
menjadi responden penelitian. Instrument penelitian menggunakan kuesioner untuk indikator petugas dan pembiayaan dengan poin pertanyaan terbuka dan tertutup. Lembar observasi digunakan untuk pengukuran indikator ketersedian standar/guidelines, ketersediaan formulir-formulir surveilans, dan komputer. Analisis data univariat dengan perhitungan persentasi untuk setiap indikator.

\section{HASIL}

Pada karakteristik responden, rata-rata umur petugas surveilans DBD adalah 49 tahun, dan $61 \%$ diantaranya adalah perempuan. Pada aspek petugas, sebagian besar responden (89\%) memiliki tingkat pendidikan diploma dengan background keilmuan kesehatan lingkungan, terdapat satu petugas surveilans Puskesmas dengan bidang keilmuan diluar kesehatan yakni pariwisata perhotelan.

Terkait jabatan rangkap yang dimiliki oleh responden di Puskesmas, sebagian besar responden (61\%) menyebutkan bahwa mereka memiliki jabatan rangkap.

Tabel 1

Karakteristik petugas (Man) surveilans

\begin{tabular}{lcc}
\hline No. & Variabel & \multicolumn{2}{c}{ Jumlah Persentase } \\
$(\mathbf{n = 1 8})$ & $(\mathbf{\%})$ \\
\hline \multirow{2}{*}{ 1. Umur } & $48,72 \pm$ \\
& $7,61^{*}$ \\
\hline
\end{tabular}

\begin{tabular}{lcc}
\hline 2. Jenis Kelamin & 7 & 38.89 \\
Laki-laki & 11 & 61.11 \\
Perempuan & & \\
\hline 3. Tingkat Pendidikan & 2 & 11.11 \\
Sarjana (S1) & 16 & 88.89 \\
Diploma (D4/D3/D2/D1)
\end{tabular}

\begin{tabular}{lcc}
\hline 4. Background Pendidikan & & \\
Keperawatan (D3) & 1 & 5.56 \\
Kesehatan Lingkungan (D3) & 14 & 77.78 \\
Kesehatan Masyarakat (S1) & 1 & 5.56 \\
Pariwisata Perhotelan (D3) & 1 & 5.56 \\
Teknik Lingkungan (S1) & 1 & 5.56 \\
\hline
\end{tabular}

5. Berapa kali mengikuti disinfo/review/pelatihan mengenai program surveilans DBD

\begin{tabular}{|c|c|c|c|}
\hline No. & Variabel & $\begin{array}{c}\text { Jumlah } \\
(n=18)\end{array}$ & $\begin{array}{c}\text { Persentase } \\
(\%)\end{array}$ \\
\hline & Belum pernah mengikuti & 5 & 27.78 \\
\hline & Sekali mengikuti & 2 & 11.11 \\
\hline & Dua kali mengikuti & 3 & 16.67 \\
\hline & Lebih dari dua kali mengikuti & 8 & 44.44 \\
\hline \multicolumn{4}{|c|}{ 6. Jumlah Jabatan } \\
\hline & 1 Jabatan & 7 & 38.89 \\
\hline & 2 Jabatan & 4 & 22.22 \\
\hline & 3 Jabatan & 4 & 22.22 \\
\hline & 4 Jabatan & 3 & 16.67 \\
\hline & Lama Bekerja sebagai & $15.97 \pm$ & \\
\hline & surveilans DBD & $11,37^{*}$ & \\
\hline
\end{tabular}

*mean \pm Standar deviasi

Tabel 2

Pembiayaan (Money) surveilans di Puskesmas

\begin{tabular}{|c|c|c|c|}
\hline No. & Variabel & $\begin{array}{c}\text { Jumlah } \\
(n=18)\end{array}$ & $\begin{array}{c}\text { Persentase } \\
(\%)\end{array}$ \\
\hline
\end{tabular}

1. Ketersediaan dana surveilans di

Puskesmas

$\begin{array}{lcc}\text { Tersedia } & 13 & 72.22 \\ \text { Tidak tersedia } & 5 & 27.78\end{array}$

2. Sumber dana

kegiatan surveilans

Puskesmas

\begin{tabular}{llc} 
APBD & 6 & 33.33 \\
APBD \& APBN & 1 & 5.56 \\
APBD \& BOK & 4 & 22.22 \\
BOK & 2 & 11.11 \\
\hline
\end{tabular}

Tabel 3

Ketersediaan SOP surveilans DBD (Method) dan Komputer di Puskesmas (Machine)

\begin{tabular}{llcc}
\hline No. & \multicolumn{1}{c}{ Variabel } & $\begin{array}{c}\text { Jumlah } \\
(\mathbf{n = 1 8})\end{array}$ & $\begin{array}{c}\text { Persentase } \\
(\mathbf{\%})\end{array}$ \\
\hline 1. & $\begin{array}{l}\text { Ketersediaan Standar } \\
\text { Operasional Prosedur }\end{array}$ & & \\
& & \\
& terkait pelaksanaan \\
& surveilans & & \\
& Tersedia & 13 & 72.22 \\
& Tidak tersedia & 5 & 27.78 \\
2. & Ketersediaan kom- & & \\
& puter di Puskesmas & & \\
& Tersedia & 2 & 11.11 \\
& Tidak tersedia & 16 & 88.89 \\
\hline
\end{tabular}


Tabel 4

Ketersediaan formulir surveilans DBD di Puskesmas(Material)

\begin{tabular}{llccc}
\hline \multicolumn{1}{c}{ Variabel } & \multicolumn{2}{c}{ Tersedia } & \multicolumn{2}{c}{ Tidak } \\
tersedia
\end{tabular}

Berdasarkan tabel 1 diatas diketahui bahwa pada indikator petugas (Man), rata-rata berumur 48 tahun dan sebagian besar adalah perempuan (61.11\%). $88.89 \%$ petugas memiliki merupakan lulusan diploma dengan latar belakang pendidikan terbanyak adalah D3 kesehatan lingkungan. Meskipun 94\% petugas surveilans DBD memiliki latar belakang kesehatan atau lingkungan, terdapat 1 orang (5.56\%) yang berasal dari pariwisata perhotelan. Pada aspek pengalaman mengikuti pelatihan, sebagian besar petugas (44.44\%) pernah mengikuti 2 kali atau lebih disinfo/ review/ pelatihan mengenai program surveilans DBD. Sebanyak 61\% petugas surveilans DBD memiliki tugas rangkap di Puskesmasnya masing-masing. Terkait lama bekerja, rata-rata petugas telah bekerja selama 16 tahun sebagai surveilans DBD di Puskesmas.

Pada aspek pembiayaan, $72.22 \%$ petugas menyatakan bahwa terdapat biaya untuk operasional program surveilans DBD dengan sumber utama adalah APBD. Berdasarkan tabel 3 diketahui bahwa 72.22\% Puskesmas memiliki guidelines dan Standard Operating Procedure(SOP) surveilans DBD. Dalam hal ketersedian komputer, 88.89\% Puskesmas memiliki komputer untuk pengolahan dan analisis data.Pada aspek ketersediaan formulir, lebih dari $38 \%$ Puskesmas tidak tersedia formulir K-DBD, W2 DBD, KD/PKM, dan DP-DBD.

\section{PEMBAHASAN}

Hasil penelitian menunjukan bahwa rata-rata umur petugas surveilans DBD di Puskesmas adalah 48.72 tahun yang mana angka tersebut dapat digolongkan sebagai kategori tua. Berdasarkan Peraturan Pemerintah (PP) Nomor 11 Tahun 2017 tentang Manajemen Pegawai Negeri Sipil, usia pensiun untuk pejabat administrasi, pejabat fungsional ahli muda, pejabat fungsional ahli pratama, serta pejabat fungsional keterampilan adalah 58 tahun dan sebagian besar petugas surveilans Puskesmas Kota Yogyakarta masuk kedalam kategori ini.Apabila dilihat dari PP tersebut, maka rata-rata umur petugas sudah mendekati masa pensiun. Selain dilihat dari regulasi nasional, umur juga berpengaruh terhadap performance ditempat kerja. Berdasarkan Safari, et.al (2013), terdapat hubungan yang signifikan antara Work Ability Index (WAI) dengan umur, semakin tua umur seseorang maka kemampuan bekerjanya juga semakin menurun.

Pada aspek latar belakang pendidikan, menurut Keputusan Menteri Kesehatan No. 1116/SK/ VII/2003, dalam penyelenggaran surveilans, setiap Puskesmas wajib memiliki minimal 1 orang tenaga epidemiologi terampil. Akan tetapi pada kenyataannya masih terdapat petugas dengan latar belakang yang berbeda bahkan diluar rumpun kesehatan. Menurut Rahayu (2012), agar dapat menjalankan pelayanan kesehatan yang bermutu 
maka dibutuhkan beberapa hal yang mana salah satunya adalah tenaga kesehatan yang memenuhi kualifikasi. Dalam hal pengalaman mengikuti disinfo/ review/pelatihan mengenai program surveilans DBD, $72.22 \%$ petugas Puskesmas Kota Yogyakarta pernah mengikuti minimal satu kegiatan tersebut dan $61.53 \%$ diantaranya pernah mengikuti pelatihan terkait surveilans DBD lebih dari 2 kali. Pelatihan ini sangat dibutuhkan agar petugas menjadi terampil dalam menjalankan kegiatan surveilans (Maharani et al, 2014) Segala bentuk pelatihan bertujuan sebagai refreshing dan peningkatan pengetahuan khususnya aspek kognitif. Menurut Chung et.al (2015) terdapat hubungan signifikan antara pelatihan dengan peningkatan pengetahuan konginitif pekerja. Sebanyak $61 \%$ petugas memiliki lebih dari 1 jabatan di Puskesmasnya. Double job baik secara langsung ataupun tidak langsung dapat mengganggu pelaksanaan tugas surveilans khususnya dalam hal pembagian waktu kerja (Anggraini et.al, 2016).

Dalam aspek pembiayaan, masih terdapat $27.72 \%$ petugas yang menyatakan bahwa tidak terdapat alokasi dana khusus untuk operasional kegiatan surveilans DBD. Pendanaan atau biaya merupakan salah satu indikator penting untuk berjalannya sebuah organisasi, ketiadaan pendanaan akan mengakibatkan organisasi tidak dapat menjalankan programprogram yang telah direncanakan Berdasarkan aspek ketersediaan method dan machine), lebih dari 70\% Puskesmas telah menyediakan SOP dan komputer yang digunakan sebagai guidelines dalam pelaksanaan dan pengolahan data surveilans DBD (Mufidz, 2016).

Indikator terakhir dalam evaluasi surveilans adalah material, yakni ketersediaan formulir-formulir untuk pelaporan rutin. Berdasarkan hasil temuan, dilebih dari 38\% Puskesmas tidak tersedia formulir K-DBD, W2 DBD, KD/PKM, dan DP-DBD. Padahal menurut Dirjen Pengendalian Penyakit dan Penyehatan Lingkungan (2011) disebutkan bahwa setiap Puskesmas wajib melaporkan kasus infeksi dengue yang dapat didiagnosis di Puskesmas dalam waktu 24 jam menggunakan form KD-PKM DBD. Selain itu Puskesmas juga wajib membuat laporan pada formulir K-DBD, rekapan W2 sebagai rekapan mingguan, dan formulir kasus DBD perorangan (DP-DBD).

\section{SIMPULAN}

Berdasarkan hasil penelitian diketahui beberapa kekurangan pada indikator - indikator input kegiatan surveilans DBD di Kota Yogyakarta. Temuan major yang didapatkan antara lain pada aspek umur dan jumlah jabatan rangkap (Man), serta ketersedian formulir khusunya formulir yang wajib diisi dan dilaporkan oleh Puskesmas seperti formulir K-DBD, W2 DBD, KD/PKM, dan DP-DBD. Saran yang dapat diberikan antara lain peremajaan petugas surveilans DBD Puskesmas dan melakukan rekrutmen petugas baru untuk melengkapi kurangnya jenis-jenis tenaga kesehatan di Puskesmas yang nantinya diharapkan petugas dengan jabatan rangkap akan berkurang.

\section{DAFTAR PUSTAKA}

Anggraini, R., D., Chatarina, U.W., Bambang, W.K. (2016). Evaluasi Sistem Surveilans Campak di Dinas Kesehatan Kabupaten Bangkalan. Jurnal Wiyata. 3(2): 174-186.

CDC. (1988). Guidelines for Evaluating Surveillance System. Atlanta: Center for Disease Controls and Prventions

Chung, J., Park, J., Cho., M., Park, Y., Kim, D., Yang, D., Yang, Y. (2015). A Study on The Relationships Between Age, Work Experience, Cognition, and Work Ability in Older Employees Working in Heavy Industry. J. Phys. Ther. Sci. 27(1): 155-157.

Dinas Kesehatan Kota Yogyakarta. (2015). Profil Kesehatan Kota Yogyakarta Tahun 2015, Yogyakarta: Dinas Kesehatan Kota Yogykarta.

Direktorat Jenderal Pengendalian Penyakit dan Penyehatan Lingkungan (2011). Modul Pengendalian Demam Berdarah Dengue. Jakarta: Kementerian Kesehatan RI.

Keputusan Menteri Kesehatan No. 1116/SK/ VII/2003 tentang Pedoman Penyelenggaraan Sistem Surveilans Epidemiologi Kesehatan.

Maharani, B.E. and Hargono, A., 2014. Measles Surveillance Attributes Assesment Based on The Puskesmas Surveillance Officers Perception in Surabaya. Jurnal Berkala Epidemiologi 2(2): 174-186. 
Mufidz, M. (2016). Evaluasi Input Sistem Surveilans Demam Berdarah Dengue di Dinas Kesehatan Kab. Tegal. Unnes Journal of Public Health. 5(2): 156-166.

Peraturan Menteri Kesehatan Nomor 45 Tahun 2014 Tentang Penyelenggaraan Surveilans Kesehatan. Lembaran Negara Republik Indonesia. Jakarta.

Peraturan Pemerintah (PP) Nomor 11 Tahun 2017 tentang Manajemen Pegawai Negeri Sipil.

Rahayu, T, 2012, Evaluasi Pelaksanaan Program Pencegahan dan Penanggulangan Penyakit Demam Berdarah Dengue di Wilayah Kerja Puskesmas Ketapang 2 (Studi di Kecamatan Mentawa Baru Ketapang Kabupaten
Kotawaringin Timur Propinsi Kalimantan Tengah), Jurnal Kesehatan Masyarakat, Vol. 1, No. 2, Tahun 2012, Hal. 479 - 492.

Safari, S., Akbari, J., Kazemi, M., Mououdi, M.A., M.B. (2013). Personnel`s Health Surveillance at Work: Effect of Age, Body Mass Index, and Shift Work in Mental Workload and Work Ability Index. Journal of Environmental and Public Health. Vol.2013: 1-6.

WHO, (2006). Communicable disease surveillance and response systems. Guide to monitoring and evaluating.

WHO. (2012). Global Strategy For Dengue Prevention And Control. Swiss : WHO Press. 